\title{
Using socioeconomic system analysis to define scientific needs: a reverse engineering method applied to the conversion of a coal-fired to a wood biomass power plant
}

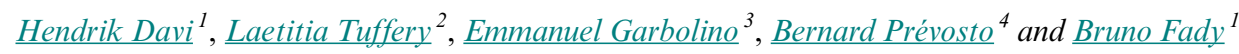

\begin{abstract}
One of the greatest challenges when addressing issues in complex social-ecological systems (SES), is the need for an efficient interdisciplinary framework when large-magnitude social and ecological disturbances occur. Teams comprising of scientists from different backgrounds and disciplines are frequently called upon to propose research methods and results that can be useful for policy and decision makers. However, most of the outcomes from these pluri-disciplinary teams appear extremely difficult to implement within a bigger picture because concepts, hypotheses, methods, and results are specific to each discipline. Here, we propose a reverseengineering (RE) method to define the scientific needs that could help policy makers and citizens to assess the impacts of socioeconomic "disruptors" on social-ecological systems. We present this method using the example of an ongoing wood biomass energy plant (Gardanne) in the French Mediterranean region. In the Mediterranean region, species diversity is high, the forest cover is ample, but difficult access and low forest productivity make any biomass policy an ecological and social disruption. Our method is based on three complementary approaches to (1) describe the social-ecosystems, (2) draw up a map of interactions between actors and the impacts on the ecosystem, and (3) identify relevant questions needed for a global analysis of the impacts and potentialities of adaptation of actors and the ecosystems to the perturbation and the connections needed between the different disciplines. Our analysis showed that knowledge gaps have to be filled to assess forest resource vulnerability and better estimate how the different resource used (solid wood, biomass, landscape) competed together. Finally, we discuss how this method could be integrated into a broader transdisciplinary work allowing a coproduction of knowledge and solutions on a SES.
\end{abstract}

Key Words: forest; interdisciplinary; model; reverse-engineering; wood energy

\section{INTRODUCTION}

Social-ecological systems (SES) are linked systems of people and nature, emphasizing that humans must be seen as a part of, and not apart from, nature (Berkes et al. 1998). There is a widespread consensus in the literature of SES that not only several scientific disciplines are needed to address the complex problems emerging in SES, but also a sound interdisciplinary framework. It should aim at bringing together scientists from a variety of scientific disciplines to share their points of view to analyze a system, and achieve useful policy results for ecosystem management (Angelstam et al. 2013). Interdisciplinarity is obviously only a first step, because addressing sustainability challenges is most effective when "coproduced" by academics and nonacademics in a true transdisciplinary approach (Norström et al. 2020). One of the main difficulties of these transdisciplinary approaches is the empowerment capacity of the practitioners. A true interdisciplinary synthesis can be therefore an important first step to gain the confidence of nonscientific actors, which is a prerequisite for their engagement in the rest of the process, because it increases the likelihood that the resulting knowledge is perceived by end-users as credible and legitimate.

This interdisciplinary framework is especially critical when large disturbances affect SES. Disturbances, defined as infrequent and strong changes in environmental or social conditions that significantly affect the functioning and diversity of an ecosystem (Dornelas 2010), can originate from natural disasters, but also from unsuited top-down or local policies that have not gone through consultation processes. The latter case is particularly widespread as many policies created with good intent at the higher levels of administration can have negative effects at the local level (Blake 1999).

Assessing the effects of SES disrupters is a necessary first step for improving SES resilience. This must cut across the interests and knowledge of the various actors, whether public or private, and incorporate both scientific and local knowledge. This form of interaction between science and society faces several challenges. First, there must be a good match between scientific knowledge and engineering needs for a proper analysis of SES dynamics. This requires a precise analysis of the SES in its different dimensions. Second, technical obstacles need to be removed. Sometimes scientific knowledge is theoretically available, but time-consuming engineering work may be required to answer certain questions. Third, in rarer cases, a scientific answer requires scientific breakthroughs. They must be highlighted from the beginning of the SES analysis process, because making progress on these scientific frontiers can be long. Fourth, real interdisciplinary work must be undertaken to evaluate the dynamics of SES following disruption. Sometimes it is necessary to find common metrics to compare different scenarios and different services provided by ecosystems.

In this paper, we use a bottom-up approach to address a complex social-ecological problem: the installation of a very large wood biomass power plant in Provence (southeastern France) that will consume a significantly large share of the wood produced in the neighboring regions. Using wood biomass has been seen as an efficient way for energizing a stalling forestry sector, creating jobs,

${ }^{1}$ INRAE, URFM, Avignon, ${ }^{2}$ Univ Montpellier, CNRS, INRAE, Institut Agro, CEE-M, Montpellier, ${ }^{3}$ Climpact Data Science, ${ }^{4}$ INRAE, Aix Marseille Univ., RECOVER, le Tholonet 
solving energy needs, and mitigating greenhouse gas emissions to reach the thresholds set in the Paris Climate Agreement of 2015. However, the installation of one of the largest biomass-based power stations in France raises questions about short- and longterm sustainability (Leroux 2016). Particularly, the wood sector actors of the area are not prepared for new demands and public concerns over biodiversity conservation, landscape destruction, and health issues are very high (Upreti and van der Horst 2004).

In this paper, using a reverse engineering approach, we identify the research challenges needed to be addressed, the main questions that have emerged, and the links needed between scientific disciplines to more efficiently conduct research on SES. We also discuss how this method could integrate a more transdisciplinary approach.

\section{METHOD}

We used an original three-step reverse-engineering methodology to assess interdisciplinary research needs using this case study. In engineering sciences, reverse engineering is the process of studying an object to determine its internal function or manufacturing method (Bagci 2009). By analogy, here it is the study of a disturbed SES, in order to deduce in a pragmatic way, what are the interactions among the scientific issues that are linked to it. The basic idea is to disentangle the system under study into its parts and see how they interact with each other. First, we describe the rationale that fits the need for nonavoidable interdisciplinary work. Second, we delfine the SES and draw its map of actors as a first step to reverse engineer the research challenge. Third, building from this map of actors, we assess the knowledge and technical gaps that exist to answer the many questions of the actors, concerning the use of the resource and the interactions between actors. This method also meets two of the criteria given by Norström et al. (2020) for an efficient coproduction of knowledge between scientists and practitioners and solutions to increase the sustainability of SES: It is context-based and goaloriented. This approach is another way of formalizing the methods of science-policy relations on sustainability and SES research already described in the literature (Olsson et al. 2004, Walker et al. 2004, Armitage et al. 2012, Ban et al. 2013, Holzer et al. 2019).

This method was implemented in the framework of a research project funded by the Man and the Environment Observatory of Provence (https://www.ohm-provence.org/). This project led to the creation of a consortium and the organization of a working group of about 15 scientists, whose theme was the scientific stakes of the conversion of the Gardanne power plant from charcoal to wood biomass. The scientists who contributed to this consortium represented different disciplines (forest ecology, economics, sociology, law, forestry, energy). The results of their work were then regularly communicated to forest stakeholders, interest groups, and citizens' associations. Most of the scientists involved work on applied research topics and have remained in permanent contact with the stakeholders involved in this power plant project. It was therefore possible to take stock of the various issues at stake by bringing together these different scientists, knowing that each of them was already in contact with private landowners, forest managers, citizens' associations, and interest groups.

\section{FIRST PHASE: PROBLEM SETTING}

The development of the biomass energy sector in France

The current goals of a sustained or even increasing production of wood biomass are to jointly help mitigating greenhouse gas effects and increasing the contribution of wood biomass to energy production (Pan et al. 2011, Fytrou-Moschopoulou 2015). The wood biomass, mainly of forest origin, accounts for 9.1 Mtoe. year $^{-1}$ (Ministerial Statistical Service of Agriculture 2019; 39.8\% of renewable energies) and results in a sharp increase in the amount of wood harvested in France to produce energy (Fig. 1). Cogeneration, i.e., joint production of electricity and heat, has been developing since 2004, with regular calls for tender by the Commission for the Regulation of Energy (CRE), an independent administrative body in charge of regulating the French electricity and gas markets.

Fig. 1. Temporal evolution of wood harvested (total, for fuel, for industry, and for log purposes) in France (left) from 1948 to 2015 and in Provence region (PACA), from 2005 to 2015 (right) in Million $\mathrm{m} 3$ obtained from the Ministerial Statistical Service of Agriculture (2019).

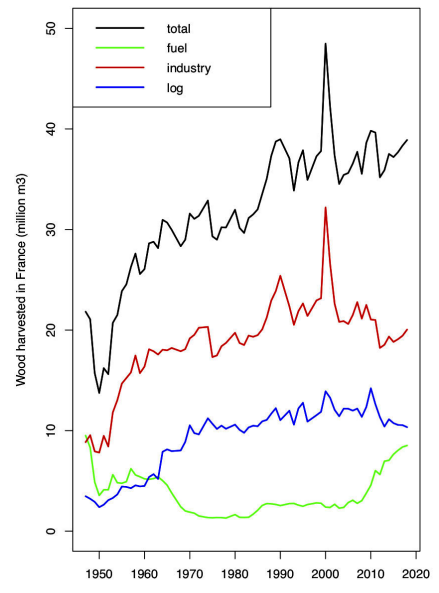

year

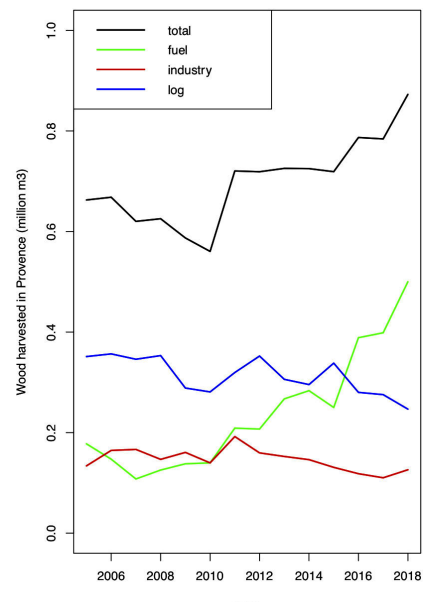

year

\section{The installation of the power station}

In the 19th and 20th centuries, the coal extracted from the underground around Gardanne accompanied the industrial development of the Marseille region (Daumalin et al. 2005). The power plant that used coal from these mines was built in several phases from 1953 to 1967 . The mine closed in 2003 and the power plant then used imported coal. In February 2011, the German company UNIPER (https://www.uniper.energy/), submitted a biomass power plant project to the CRE4 (https://www.cre.fr/en/ CRE/who-are-we) call for proposals, which was successful. The wood biomass power plant is expected to produce $150 \mathrm{MW}$ and must use at least $50 \%$ of its biomass from within a radius of 250 $\mathrm{km}$. The project has been heavily criticized in particular because of its overall low energetic efficiency of $40 \%$, because there is no recovery of heat (Seuret 2015). Also, the required biomass resource will be very large with a strong impact on local and regional resources, and many stakeholders opposed the project (Leroux 2016). In June 2017, the Administrative Court of Marseille canceled the operating authorization granted by the 
Fig. 2. Map of the social-ecological system and gap of knowledge. PACA, Provence-Alpes-Côte d'Azur region.

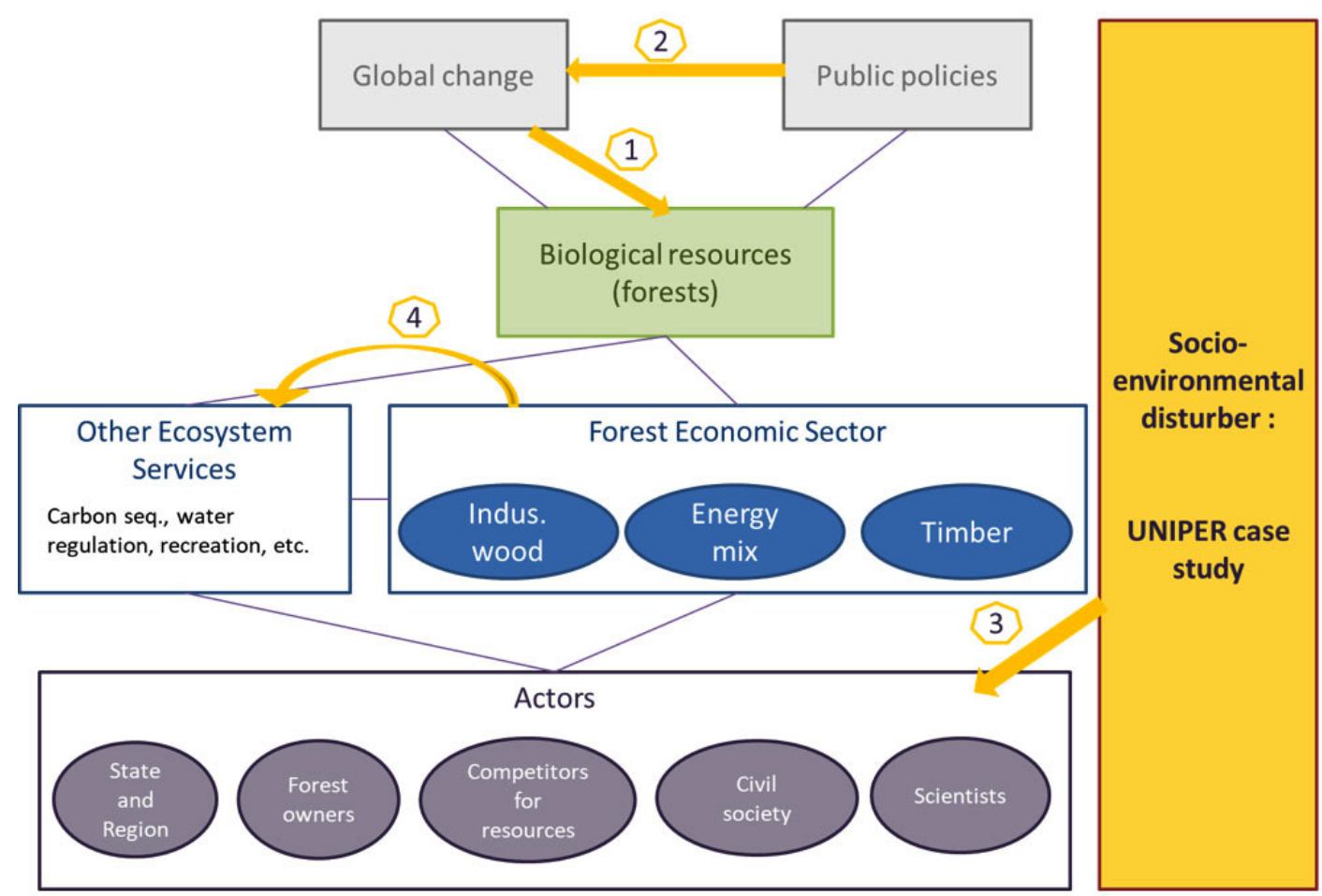

1) Will the PACA forest decline because of climate change?

(2) Which type of silviculture to mitigate global change?

3 How to mobilize wood in a homogeneous way in a fragmented landscape?

4 How will other ecosystem services be affected by intensification of production?

\section{Knowledge gaps}

— General relationships

State in 2012 on account of the lack of sufficient impact assessments on forest resources (Bourbon 2017). However, the Prefect (as the regional representative of the French Government) overruled the decision and allowed the provisional, but immediate continuation of exploitation, demanding that UNIPER provide an assessment report of the impact of the operation on the local forest resources (Leroux 2017). Finally, in July 2019, the Czech group EPH bought the Gardanne power plant (Wakim 2019). The SES studied is therefore subject to economic and capitalistic issues that go beyond ecological issues.

\section{Forest resources are fragmented and difficult to access}

The increase of forest area per year between 1985 and 2018 was higher in the Mediterranean area than in the rest of France (IGN 2019). The Mediterranean forest is also considered underexploited. For example, the "harvest / forest production" ratio is $22 \%$ in the Provence-Alpes-Côte d'Azur administrative (PACA) region, while the national average is $52 \%$ (Inventaire
Forestier National 2019). There is therefore a considerable margin for economic growth for wood energy programs. However, only $22 \%$ of the volume of standing timber $\left(25\right.$ million $\left.\mathrm{m}^{3}\right)$ is identified as easily exploitable(OFME2018). Furthermore, the productivity of the forest is low and estimated at $1.92 \mathrm{~m}^{3} \cdot \mathrm{ha}^{-1}$.year ${ }^{-1}$ compared to $5.0 \mathrm{~m}^{3}$.ha $\mathrm{a}^{-1}$.year ${ }^{-1}$ at the national level (Inventaire Forestier National 2019).

\section{SECOND PHASE: MAPPING THE ACTORS OF THE SES}

The delineation of the studied social-ecological system

The spatial scale of the studied SES is defined here by the topdown policies that are implemented in the PACA region. Political decisions were taken at this scale, even if the wood biomass supply needed for operating the power plant is wider (Fig. 2).

\section{Climate}

The latest Intergovernmental Panel on Climate Change scenarios are presented spatially in Annex I of their 2014 report (IPCC 
2014). For Southern Europe and the Mediterranean area, summer temperatures (June-August) will increase by 1 to $9{ }^{\circ} \mathrm{C}$ and precipitation from April to September will decrease by 0 to $25 \%$ depending on the socioeconomic scenario (IPCC 2014). A temperature increase of $0.88^{\circ} \mathrm{C}$ was observed between 1860 and 2005 while a decrease in annual precipitation of $23 \mathrm{~mm}$ was observed between 1902 and 2005 (Mariotti et al. 2015). In addition, temperature and precipitation interact with changes in $\mathrm{CO}_{2}$ content, in atmospheric nitrogen composition with an expected increase of $71 \%$ in nitrogen deposition between 1990 and 2050 for Mediterranean basin (Phoenix et al. 2006) and atmospheric pollution especially in $\mathrm{O}_{3}$ (Paoletti 2006). One of the main consequences of climate change is an increase in the intensity of water stress (Nicault et al. 2008).

\section{European Union, French State, and the PACA region}

The European Union (EU) will reduce its domestic greenhouse gas emissions by $40 \%$ by 2030 (General Secretariat of the European Council 2014). In France, since 2007, energy transition policies have led to a harvesting turn within the French forest policy framework, meaning that priority is given to wood mobilization, mainly for biomass uses (Sergent 2014). In this context, France has set a target of using $23 \%$ renewable energy sources by 2020 and biomass should account for $45 \%$ of the overall renewable energy effort (Sergent 2014). The PACA region has translated these incentives into its regional biomass plan (http://www.paca.developpement-durable.gouv.fr/schema-regionalbiomasse-provence-alpes-cote-d-a11313.html).

\section{Forest owners}

The way the bioenergy sector can impact landscapes also depends on the land tenure regime. The forest ownership is largely private in PACA ( $68 \%$ of the forest area; IGN 2010) and very fragmented. There are 218,000 private forest owners, $67 \%$ of whom own less than 1 ha, whereas $2 \%$ of them own $45 \%$ of the private forest area (IGN 2010). Consequently, only $46 \%$ of forests owners have a valid management plan. The risk of clear-cutting is therefore important. However, it must be noted that both public and private forest owners also consider the power plant project as an opportunity for a better commercialization of their products.

\section{Competitors for resources}

The recent harvest of wood in the PACA region alone was 872,000 $\mathrm{m}^{3}$ in 2018 with an increasing share of energy wood (Fig. 1). The biomass resource required by the UNIPER power plant project represents 850,000 tons per year, of which 600,000 tons (equivalent to $500,000 \mathrm{~m}^{3}$ ) of forest products is expected to be harvested locally within a radius of $250 \mathrm{~km}$ around the plant by 2025. The resource required by the new wood biomass power plant constitutes almost a 70\% increase of the current regional demand. But, this resource will not come only from the PACA region: the plan presented to the Biomass Regional Committee on 18 February 2015 gives a figure of 221,000 tons forecast for PACA by 2025 . Moreover, this project adds up to existing plants in the PACA Region, in particular a paper mill (located in Tarascon) that uses $1,150,000$ tons of wood annually and a biomass power plant (Inova Var located in Brignoles) using 140,000 tons of forests product annually. There are also numerous small, mostly communal boilers that were developed as part of community action toward sustaining their energy consumption using renewable energy sources. All of these economic players, particularly those with communal boilers, fear a competition for resources with the installation of new wood biomass power plant.

\section{Civil society and political parties}

The Regional Natural Parks of the Verdon and Luberon, located nearby, have opposed the project, which they see as threatening the sustainability of the forests they manage (http:// parcduverdon.fr/fr/actualites/mobilisation-pour-les-forets-du-verdonet-du-luberon). Local environmental associations and unions consider that there are problems both in terms of forest and biodiversity preservation, and pollution by fine particles. Moreover, the power plant policy will probably have an effect on many ecosystem services: hunting, mushroom picking, tourist attractiveness. Some political parties have relayed these views and today 200 municipalities in the region and 250,000 petitioners voted a motion against the wood power plant (https://www. sauvonslaforet.org/petitions/959/uniper-veut-bruler-les-forets-francaisesa-gardanne).

\section{The scientific community}

Some scientists have been asked by the biomass plant to estimate the sustainability of the wood supply. Others also gave elements concerning the same topic to the interest groups that brought the case to court. Some scientists also met foresters to discuss the already observed and future effects of the power plant's presence on forestry operations. These exchanges also enabled scientists to better understand the various issues related to the SES under study. However, in a tense context among the different protagonists, scientists are in a rather difficult position. They can very quickly be accused of favoring one side against the other and their objectivity is then questioned.

\section{THIRD PHASE: EVALUATE THE KNOWLEDGE GAPS}

This description of the case study and the interaction with foresters and civil society allowed us to build the map of the actors of this system and define the stakes (Fig. 2): externalities (global change and public policies); biological resources (in this case mainly forests and secondarily agriculture and urban green waste); products derived from these forest resources (industrial wood, energy mix, and timber), and the other services they offer (for instance, carbon sequestration, protection against soil erosion, water regulation, and supply); and finally the various actors (the state and the region officials, the forest owners, the competitors for the resources [Gardanne and Brignoles power stations, the small boilers, and the paper mill], the civil society, and the scientific community).

From this map of the SES, it is possible to deduce a certain number of questions raised by the different actors. Then one of the roles of the scientists involved is to translate these societal issues into scientific questions. In some cases, a juxtaposition of the data is sufficient. In other cases, it is necessary to move forward on some scientific frontlines. Starting from our case study, we studied a number of scientific issues raised by the new power plant.

Will PACA forests decline because of climate change?

The evolution of resource availability in the future in the context of climate change is a first point to be addressed. Increasing $\mathrm{CO}_{2}$ can initially increase forest productivity (Saxe et al. 1998, Norby et al. 2005, Davi et al. 2006) and could even compensate negative effects due to temperature increase and water limitation by improving water-use efficiency (Keenan et al. 2013). However, this 
effect can stop quite rapidly (Norby and Zak 2011), in particular via the existence of other limiting factors such as nitrogen or ozone (Paoletti 2006) and it is usually admitted that forest productivity will decrease in water-limited environments (Allen et al. 2010). In the Mediterranean region, an increase in the duration and intensity of droughts may have the opposite effect and even cause massive decline (Carnicer et al. 2011, Cailleret et al. 2014, Davi and Cailleret 2017). Although studies on the evolution of wood resources have been conducted at large scales (Guillemot et al. 2014, Lindner et al. 2014), studies also have to be carried out at regional scales because of the diversity of situations resulting from the diversity of pedoclimatic conditions (Verkerk et al. 2015) and the diversity of uses (Verkerk et al. 2014) in the Mediterranean bioclimatic context (Garbolino et al. 2017).

To estimate the evolution of different types of resources at this regional scale, it is necessary to have models of forest dynamics parameterized on each species of interest and which consider the effect of climate change. Current models do not sufficiently couple the components of growth (photosynthesis, respiration, wood growth) and those of demographic dynamics (reproduction, regeneration, and survival). To reach this goal, information on the main ecological traits for the different species such as growth, reproduction, drought tolerance, light requirement, is absolutely needed, but ecological databases are clearly lacking. To overcome these obstacles, plant physiology researchers must work more with foresters and managers to test different management scenarios that can sustain forest productivity in a climate change context. Scientific issues are mainly located in various ecological fields, e.g., genetics, ecophysiology, silviculture, plant dynamics, etc., and involve the use of computer simulations and the establishment of ecological databases.

\section{Which type of silviculture to mitigate global change?}

Forestry practices can change to mitigate global change (GC) impacts. This adaptation of silviculture is already widely debated within the forest community. Many measures have already been discussed: favoring the natural regeneration of stands by adapted silviculture treatments (Prévosto et al. 2012) and avoiding the detrimental effect of game on regeneration (Laurent et al. 2017), choice of new species or varieties by assisted migration (Legay et al. 2015), shortened rotations (Loustau et al. 2005), reduced stand density (Cáceres et al. 2015) or use the interactions between forestry and genetic evolution (Lefèvre et al. 2014).

Which adaptive measures will be really efficient in the Mediterranean is still unclear. For instance, replacing the current species using more drought-resistant material can be achieved by using the same species and more drought resistant provenances or by introducing new species. For this decision to be efficiently made, it is necessary to estimate the growth potential of exotic species and their provenances using the common garden in the appropriate climate. Experiments also have to be carried out to study the behavior of these species in field conditions, in particular the interactions with the resident vegetation and fauna. We must also accurately assess the risk of introduction of exotic species by better knowing the traits that lead a species to be invasive in our environment. The effect of rotational shortening or density reduction can be investigated experimentally (Gavinet et al. 2015, Guillemot et al. 2015). Dynamic models integrating water stress could complement these experimental approaches and should be used on species of interest in the Mediterranean region. The interactions between genetic evolution, climate, and silviculture are more difficult to study, but physio-demo-genetic models are beginning to be developed to study these questions (Oddou-Muratorio and Davi 2014).

\section{How to mobilize wood in a homogeneous way in a fragmented landscape?}

UNIPER's supply plan is supposed to target forests within a radius of 250 to $400 \mathrm{~km}$ around the Gardanne power plant (Bourbon 2017). The accessibility of the resource is therefore a major issue. The efficient exploitation of forests depends not only on the existence of a sufficient quantity of resources, but also, and to a great extent, on their accessibility. The wood sector is poorly structured in the PACA region. The density and quality of the service road network conditions determine a part of the logging potentialities. It is noteworthy that in a review of current practices in logging operations in European mountains, Enache et al. (2016) showed that the lowest efficiency and the highest environmental footprint were reported for nonmechanized or obsolete harvesting systems while the reverse was true for fully mechanized and adapted systems. It must be noted that intensification of harvesting operations requires more powerful and efficient vehicles, which are also heavier and can negatively affect soil properties such as soil compaction leading to reduction of soil permeability, destruction of soil porosity, and modification of water retention (Cambi et al. 2015). However, this difficulty must be put into perspective. Indeed, if the price of wood increases, the construction of forest roads becomes more profitable. On the other hand, forestry companies can adapt to difficult conditions and develop techniques and equipment to extract wood in steep slopes areas. For instance, cable yarders are the appropriate extraction technology in steep terrain, but they require a well-developed road network (Enache et al. 2016). The mobilization of wood is thus made difficult by the fragmentation of the landscapes but also of the property division.

Scientific issues are mainly located within the economic, geographic, and legal fields. We must determine what the economic and legal levers are that will allow the development of forest roads. It is also necessary to better study the impacts of overexploitation of forests in mountain areas with steep slopes. Finally, we must find the legal or social means that allow a more homogeneous wood mobilization between the different types of owners by avoiding clear-cut on the one hand and under exploitation on the other hand. To reach this goal, it may be necessary to adapt legislative and administrative rules. Science can also provide means of posteriori control of landscape evolution by developing tools to detect early disturbance signals. For example, it is possible to map the intensity of logging by remote sensing (Magnusson et al. 2008).

\section{How will other ecosystem services be affected by intensification of production?}

An uncontrolled production increase in the wood-energy sector can negatively impact biodiversity and other services provided by forests (Zhang et al. 2000, Deconchat and Balent 2002). However, in the Mediterranean region a regime of well-distributed, small harvesting will maintain local, small disturbances that can 
actually increase diversity. Studies have shown that the influence of forest management on biodiversity is contrasted among taxonomic groups; for instance, it is positive for vascular plants, but negative for saproxylic organisms (Bouget et al. 2012) and variable in time (see Paillet et al. 2010 for a review). It is noteworthy that intense logging is often detrimental to forest ecosystems because, for instance, of soil compaction, loss of nutrients through intensive wood harvest that can also alter soil fertility. The impact of harvesting on soil erosion and runoff is often discussed (Croke et al. 2001), even an experimental proof is not always found (Hartanto et al. 2003). They can also impact other economically important activities such as recreational activity and tourism (Gundersen and Frivold 2008). Finally, a positive or a negative interaction is also possible between the "wood energy" service and fire risks. On the one hand, forest activities are sometimes a source of wildfires (see Prométhée statistics, http:// www.promethee.com/). On the other hand, higher wood use will lower biomass and fuel and decrease the risk of fire (Marino et al. 2012).

It is necessary to better evaluate all the ecosystem services provided by these forest ecosystems. This assessment requires work involving ecologists, soil scientists, geologists, hydrologists, and economists. Some theoretical work has already discussed the impacts of economic policies for wood energy sector development on forest resource (Caurla et al. 2013). However, studies are still few in this area and information is still missing. For example, the effect of public policies and demand scenarios (or shocks) on local wood resources, the forest sector, ecosystem services provision, and employment at a local scale and introducing a spatial explicit approach is missing; the evolution of wood market prices, supply and demand at different scales (from regional to global) according to the wood energy sector development is necessary. More generally, this type of economic research must also involve sociologists, because the price signal is not the only driver of choice for actors of an environment where habits can play an important role.

\section{DISCUSSION}

The establishment of UNIPER is politically very sensitive. This makes it difficult to produce an objective discourse. There could also be multiple conflicts of interest. For instance, the French National Forest Service (ONF) is a major player in forest management, through either direct management of state forests or the definition of management plans for other public or private forests. Nevertheless, the ONF is directly interested in the sale of wood to the wood energy sector, through its ONF energy subsidiary. Also, in the many reports produced by different actors, scientific references are very scarce.

The relationships between science and society can be complex. When scientists interact with different antagonistic actors, they may be accused of being manipulated or in the service of one of the actors. It seems interesting for SES analysis, to work in a threestage iterative phase. In a first step, we identify and gather the scientists who have relationships with the different protagonists. Analyzing the relationships between the scientists and the other involved parties allows us to identify the stakes and then the scientific and technical challenges. In a second step, the scientists work in an interdisciplinary way on these scientific challenges to identify in particular what is known (state of the art) and what are the knowledge gaps. Finally, in a third phase, reuniting the scientists with the actors, allows to broaden the work in a more transdisciplinary approach defined as a research approach that includes multiple scientific disciplines (interdisciplinarity) focusing on shared problems and the active input of practitioners from outside academia (Brandt et al. 2013). In a way, this iterative approach also helps to preserve the independence of scientific expertise on scientific challenges and limit power imbalances during the process (Norström et al. 2020) because some economic or political actors can have strong interests and distort the expertise.

The case study presented here rather concerns the second phase of this three-stage iterative process, because it is the one that was really organized and thought out in the framework of a dedicated project. In our case study, we answered three of the four challenges listed in the introduction: (i) we assessed the scientific knowledge and engineering needs for a proper analysis of the SES dynamics, (ii) we determined some technical obstacles, and (iii) we highlighted the scientific breakthroughs. But we did not evaluate the dynamics of SES following disruption.

In the long term, it will obviously be necessary to move toward the third phase in a truly transdisciplinary approach to advance toward this last objective. But to be efficient, practitioners' empowerment is necessary, which is rarely the case (Brandt et al. 2013). We believe that an initial synthesis of the scientific and technical issues by the scientists themselves (this publication and the different meetings before it) is likely to lay the foundations for true coconstruction of solutions based on boundary work ( $\mathrm{Nel}$ et al. 2016), which may take the form of scenarios for the evolution of ecosystem services, for example.

Scientific results particularly in the fields of ecological and socioeconomic sciences are usually complex and do not lead to simple responses. As a consequence, they often lack an operational translation regarding ecological transition and the sustainable development of our societies. This gap has at least three sources. The first is the lack of analysis concerning the real scientific obstacles that prevent us from responding to societal issues. In our case study, this is particularly true of forest ecology research on adaptation, dieback, and fire risks in the context of global warming and of multiple and sometimes contradictory demands on forest services. In both cases, the gap of knowledge concerns transfer tools rather than fundamental knowledge. The evolution of the fire (Moriondo et al. 2006) or drought risks (Xu et al. 2019), as well as the determinants of land use changes (Serra et al. 2008), are well documented. But, at present there are few or no operational tools for managers to take these risks and changes into account with the most recent fundamental knowledge. The second is the lack of interdisciplinary research on certain issues due to a traditional compartmentalization of science into disciplines. The third is the lack of engineers or researchers involved in applied research to do this type of work. This last aspect partly explains the lack of transfer tools between the fundamental knowledge used to project risks in the context of global warming and the tools used by managers to establish management plans.

One way of formalizing the dialog among disciplines is through the use of "boundary concepts" or "boundary objects," that refers to concepts or objects that are general enough to be apprehended 
by different actors (or disciplines), but specific enough to have their own meaning for each actor or discipline. For instance, "resilience" (Brand and Jax 2007, Baggio et al. 2015) and "ecosystem services" (Abson et al. 2014, Schleyer et al. 2017) have been analyzed recently in that regard. The use of the concept of "ecosystem services" is a good example. Considering the diversity of forest uses allows dialogue between different scientists working on soil erosion, carbon sequestration, fire risk, or forest production. But it also allows confrontation between actors with contrasted objectives: forest stakeholders more interested in forest production (e.g., some private forest owners), stakeholders involved in environmental protection (e.g., agents working in protecting areas) and ecological transition, who tend to focus on biodiversity preservation or carbon sequestration. In another project, we carried out this type of study bringing together the same different types of stakeholders to estimate the evolution of ecosystem services provision in a regional natural park and under different socioeconomic scenarios, one of them being the development of the Gardanne power station whose supply area includes the park itself (L. Tuffery, H. Davi, N. López-García, et al., unpublished manuscript). We have seen how seemingly irreconcilable differences in disciplinary backgrounds, concepts, language, and methodologies between the different actors can be overcome when discussions use the same metric to quantify ecosystem services.

In contrast to the boundary approach, a large wealth of interdisciplinary research in sustainability science is done with problem-oriented, bottom-up approaches (Kates 2011) in which the issues themselves call for the disciplines required to address a specific sustainability problem. In this case, the link between the different actors does not involve the definition of a metric associated with a boundary concept, but the precise and interdisciplinary analysis of a concrete case study. This analysis requires the definition of stereotypes and concepts specific to each of the disciplines. The main risk involved with this approach is that it is not guaranteed that the different disciplines will dialogue efficiently. This risk can be overcome in a truly transdisciplinary stage that methodically ensures the pluralistic composition of the actors involved (Norström et al. 2020).

A reverse engineering method as we have described it in this work is a way to formalize an interdisciplinary analysis of a given problem from a case study on a perturbation of an SES. We believe that this reverse engineering method described here can improve the link between science and society, overcome the scientific obstacles, and promote a true interdisciplinary work. In our case study, it enabled us to define an SES, to define the different actors of this system and the different societal and scientific questions related to it. We have shown that the obstacles to a better understanding of the effect of disturbance on the SES studied were both scientific and technical (database, modeling tools) and that they related to disciplines as varied as law, economics, sociology, climatology, soil science, ecology, and forestry. This bottom-up approach also helps to emerge the notion of "border tools" as process-based modeling. Nel et al. (2016) have shown how the production of maps integrating knowledge on the conservation of rivers and wetlands in South Africa allows for the coproduction of knowledge through boundary works. Similarly, discussion on producing simulation plans with processbased models and on their results (L. Tuffery, H. Davi, N. LópezGarcía, et al., unpublished manuscript), sheds light on how models can provide an interesting boundary tools as a basis for boundary works.

Finally, we think that this pragmatic approach allows us to facilitate dialogue with the citizens and the different actors, and in this sense, helps to reopen the link between science and society. This method could be applied for the management of commons, on which scientific and technical issues are real obstacles and challenges in order to make the right decisions, for instance on land use choice between forestry, agronomy, and meadows. It could also be used to decide upon a forest management strategy in a region combining forest production, biodiversity conservation, hunting, recreational activities, and landscaping.

Land use planning choices depend on the decisions of economic actors and political decisions that determine the legal framework and economic incentives. In order to make the most just decisions in terms of managing SES, it is necessary to avoid two pitfalls: (i) choices dictated by dominant economic actors who underestimate ecological externalities, (ii) choices made by civil society actors who may overestimate these same externalities. Interdisciplinary work by scientists whose objectivity is recognized by the various actors makes it possible to remove certain obstacles to optimize the management of SES.

Responses to this article can be read online at: https://www.ecologyandsociety.org/issues/responses. php/11929

\section{Acknowledgments:}

This work is a contribution to the Labex OT-Med ( $n^{\circ}$ ANR-11$L A B X-0061)$ and was funded by the Labex DRIIHM, Réseau des Observatoires Hommes - Milieux - Centre National de la Recherche Scientifique (ROHM-CNRS).

\section{Data Availability:}

These datalcode were derived from the following resources available in the public domain: https:/lagreste.agriculture.gouv. frlagreste

\section{LITERATURE CITED}

Abson, D. J., H. von Wehrden, S. Baumgärtner, J. Fischer, J. Hanspach, W. Härdtle, H. Heinrichs, A. M. Klein, D. J. Lang, P. Martens, and D. Walmsley. 2014. Ecosystem services as a boundary object for sustainability. Ecological Economics 103:29-37. https://doi.org/10.1016/j.ecolecon.2014.04.012

Allen, C. D., A. K. Macalady, H. Chenchouni, D. Bachelet, N. McDowell, M. Vennetier, T. Kitzberger, A. Rigling, D. D. Breshears, E. H. (T.) Hogg, P. Gonzalez, R. Fensham, Z. Zhang, J. Castro, N. Demidova, J.-H. Lim, G. Allard, S. W. Running, A. Semerci, and N. Cobb. 2010. A global overview of drought and heat-induced tree mortality reveals emerging climate change risks for forests. Forest Ecology and Management 259(4):660-684. https://doi.org/10.1016/i.foreco.2009.09.001

Angelstam, P., K. Andersson, M. Annerstedt, R. Axelsson, M. Elbakidze, P. Garrido, P. Grahn, K. I. Jönsson, S. Pedersen, P. Schlyter, E. Skärbäck, M. Smith, and I. Stjernquist. 2013. Solving 
problems in social-ecological systems: definition, practice and barriers of transdisciplinary research. Ambio 42(2):254-265. https://doi.org/10.1007/s13280-012-0372-4

Armitage, D., C. Béné, A. T. Charles, D. Johnson, and E. H. Allison. 2012. The interplay of well-being and resilience in applying a social-ecological perspective. Ecology and Society 17 (4):15. https://doi.org/10.5751/ES-04940-170415

Bagci, E. 2009. Reverse engineering applications for recovery of broken or worn parts and re-manufacturing: three case studies. Advances in Engineering Software 40(6):407-418. https://doi. org/10.1016/j.advengsoft.2008.07.003

Baggio, J. A., K. Brown, and D. Hellebrandt. 2015. Boundary object or bridging concept? A citation network analysis of resilience. Ecology and Society 20(2):2. https://doi.org/10.5751/ ES-07484-200202

Ban, N. C., M. Mills, J. Tam, C. C. Hicks, S. Klain, N. Stoeckl, M. C. Bottrill, J. Levine, R. L. Pressey, T. Satterfield, and K. M. A. Chan. 2013. A social-ecological approach to conservation planning: embedding social considerations. Frontiers in Ecology and the Environment 11(4):194-202. https://doi.org/10.1890/110205

Berkes, F., C. Folke, and J. Colding. 1998. Linking social and ecological systems: management practices and social mechanisms for building resilience. Cambridge University Press, Cambridge, UK.

Blake, J. 1999. Overcoming the 'value-action gap' in environmental policy: tensions between national policy and local experience. Local Environment 4(3):257-278. https://doi. org/10.1080/13549839908725599

Bouget, C., A. Lassauce, and M. Jonsell. 2012. Effects of fuelwood harvesting on biodiversity - a review focused on the situation in Europe. Canadian Journal of Forest Research 42(8):1421-1432. https://doi.org/10.1139/x2012-078

Bourbon, J. C. 2017. Nouvelles menaces sur la centrale biomasse de Gardanne. La Croix, 28 April.

Brand, F. S., and K. Jax. 2007. Focusing the meaning(s) of resilience: resilience as a descriptive concept and a boundary object. Ecology and Society 12(1):23. https://doi.org/10.5751/ ES-02029-120123

Brandt, P., A. Ernst, F. Gralla, C. Luederitz, D. J. Lang, J. Newig, F. Reinert, D. J. Abson, and H. von Wehrden. 2013. A review of transdisciplinary research in sustainability science. Ecological Economics 92:1-15. https://doi.org/10.1016/j.ecolecon.2013.04.008

Cáceres, M. D., J. Martínez-Vilalta, L. Coll, P. Llorens, P. Casals, R. Poyatos, J. G. Pausas, and L. Brotons. 2015. Coupling a water balance model with forest inventory data to predict drought stress: the role of forest structural changes vs. climate changes. Agricultural and Forest Meteorology 213:77-90. https://doi. org/10.1016/j.agrformet.2015.06.012

Cailleret, M., M. Nourtier, A. Amm, M. Durand-Gillmann, and H. Davi. 2014. Drought-induced decline and mortality of silver fir differ among three sites in Southern France. Annals of Forest Science 71:643-657. https://doi.org/10.1007/s13595-013-0265-0
Cambi, M., G. Certini, F. Neri, and E. Marchi. 2015. The impact of heavy traffic on forest soils: a review. Forest Ecology and Management 338:124-138. https://doi.org/10.1016/j.foreco.2014.11.022

Carnicer, J., M. Coll, M. Ninyerola, X. Pons, G. Sánchez, and J. Peñuelas. 2011. Widespread crown condition decline, food web disruption, and amplified tree mortality with increased climate change-type drought. Proceedings of the National Academy of Sciences 108(4):1474-1478. https://doi.org/10.1073/pnas.1010070108

Caurla, S., P. Delacote, F. Lecocq, and A. Barkaoui. 2013. Stimulating fuelwood consumption through public policies: an assessment of economic and resource impacts based on the French Forest Sector Model. Energy Policy 63:338-347. https:// doi.org/10.1016/j.enpol.2013.07.111

Croke, J., P. Hairsine, and P. Fogarty. 2001. Soil recovery from track construction and harvesting changes in surface infiltration, erosion and delivery rates with time. Forest Ecology and Management 143(1-3):3-12. https://doi.org/10.1016/S0378-1127 (00)00500-4

Daumalin, X., J. Domenichino, P. Mioche, and O. Raveux. 2005. Gueules noires de Provence: Le bassin minier des Bouches-duRhône. Jeanne Laffitte, Marseille, France.

Davi, H., and M. Cailleret. 2017. Assessing drought-driven mortality trees with physiological process-based models. Agricultural and Forest Meteorology 232:279-290. https://doi. org/10.1016/j.agrformet.2016.08.019

Davi, H., E. Dufrêne, C. Francois, G. Le Maire, D. Loustau, A. Bosc, S. Rambal, A. Granier, and E. Moors. 2006. Sensitivity of water and carbon fluxes to climate changes from 1960 to 2100 in European forest ecosystems. Agricultural and Forest Meteorology 141(1):35-56. https://doi.org/10.1016/j.agrformet.2006.09.003

Deconchat, M., and G. Balent. 2002. Effets de la sylviculture et de l'exploitation forestière sur la diversité végétale. Revue Forestière Française 54(6). https://doi.org/10.4267/2042/4943

Dornelas, M. 2010. Disturbance and change in biodiversity. Philosophical Transactions of the Royal Society B: Biological Sciences 365(1558):3719-3727. https://doi.org/10.1098/rstb.2010.0295

Enache, A., M. Kühmaier, R. Visser, and K. Stampfer. 2016. Forestry operations in the European mountains: a study of current practices and efficiency gaps. Scandinavian Journal of Forest Research 31(4):412-427. https://doi.org/10.1080/0282758$\underline{1.2015 .1130849}$

Fytrou-Moschopoulou, A. 2015. Directive 2009/28/EC of the European Parliament and of the Council of 23 April 2009 on the promotion of the use of energy from renewable sources and amending and subsequently repealing Directives 2001/77/EC and 2003/30/EC. European Union, Brussels, Belgium. [online] URL: http://www.buildup.eu/en/practices/publications/directive-200928eceuropean-parliament-and-council-23-april-2009-promotion

Garbolino, E., W. Daniel, G. Hinojos Mendoza, and V. Sanseverino-Godfrin. 2017. Anticipating climate change effect on biomass productivity and vegetation structure of Mediterranean forests to promote the sustainability of the wood energy supply chain. Pages 17-29 in 25th European Biomass Conference and 
Exhibition Proceedings, Stockholm, Sweden.

Gavinet, J., A. Vilagrosa, E. Chirino, M. E. Granados, V. R. Vallejo, and B. Prévosto. 2015. Hardwood seedling establishment below Aleppo pine depends on thinning intensity in two Mediterranean sites. Annals of Forest Science 72:999-1008. https://doi.org/10.1007/s13595-015-0495-4

General Secretariat of the European Council. 2014. European Council (23 and 24 October 2014) - conclusions. EUCO 169/14. European Council, Brussels, Belgium. [online] URL: https:// www.consilium.europa.eu/uedocs/cms_data/docs/pressdata/en/ec/145397. pdf

Guillemot, J., N. Delpierre, P. Vallet, C. François, N. K. MartinStPaul, K. Soudani, M. Nicolas, V. Badeau, and E. Dufrêne. 2014. Assessing the effects of management on forest growth across France: insights from a new functional-structural model. Annals of Botany 114(4):779-793. https://doi.org/10.1093/aob/mcu059

Guillemot, J., E. K. Klein, H. Davi, and F. Courbet. 2015. The effects of thinning intensity and tree size on the growth response to annual climate in Cedrus atlantica: a linear mixed modeling approach. Annals of Forest Science 72:651-663. https://doi. org/10.1007/s13595-015-0464-y

Gundersen, V. S., and L. H. Frivold. 2008. Public preferences for forest structures: a review of quantitative surveys from Finland, Norway and Sweden. Urban Forestry \& Urban Greening 7 (4):241-258. https://doi.org/10.1016/j.ufug.2008.05.001

Hartanto, H., R. Prabhu, A. S. E. Widayat, and C. Asdak. 2003. Factors affecting runoff and soil erosion: plot-level soil loss monitoring for assessing sustainability of forest management. Forest Ecology and Management 180(1-3):361-374. https://doi. org/10.1016/S0378-1127(02)00656-4

Holzer, J. M., C. M. Adamescu, C. Cazacu, R. Díaz-Delgado, J. Dick, P. F. Méndez, L. Santamaría, and D. E. Orenstein. 2019. Evaluating transdisciplinary science to open researchimplementation spaces in European social-ecological systems. Biological Conservation 238:108228. https://doi.org/10.1016/j. biocon.2019.108228

Institut National de l'Information Géographique et Forestière (IGN). 2010. Inventaire forestier: les données brutes. IGN, Paris, France. [online] URL: https://inventaire-forestier.ign.fr/spip. php?rubrique 270

Institut National de l'Information Géographique et Forestière (IGN). 2019. Inventaire forestier: le mémento. IGN, Paris, France. [online] URL: https://inventaire-forestier.ign.fr/IMG/pdf/ memento 2019 web-2.pdf

Intergovernmental Panel on Climate Change (IPCC). 2014. Climate Change 2014: synthesis report. Contribution of Working Groups I, II and III to the Fifth Assessment Report of the Intergovernmental Panel on Climate Change. Core Writing Team, R. K. Pachauri, and L. A. Meyer, editors. IPCC, Geneva, Switzerland

Inventaire Forestier National. 2019. Memento de l'inventaire forestier national. Institut de l'Information Géographique et Forestière, Paris, France.

Kates, R. W. 2011. From the unity of nature to sustainability science: ideas and practice. CID Workgin Paper No. 2018. Center for International Development, Harvard University, Cambridge, Massachusetts, USA.

Keenan, T. F., D. Y. Hollinger, G. Bohrer, D. Dragoni, J. W. Munger, H. P. Schmid, and A. D. Richardson. 2013. Increase in forest water-use efficiency as atmospheric carbon dioxide concentrations rise. Nature 499:324-327. https://doi.org/10.1038/ nature 12291

Laurent, L., A. Mårell, P. Balandier, H. Holveck, and S. Saïd. 2017. Understory vegetation dynamics and tree regeneration as affected by deer herbivory in temperate hardwood forests. iForest - Biogeosciences and Forestry 10(5):837. https://doi.org/10.3832/ ifor2186-010

Lefèvre, F., T. Boivin, A. Bontemps, F. Courbet, H. Davi, M. Durand-Gillmann, B. Fady, J. Gauzere, C. Gidoin, M.-J. Karam, H. Lalagüe, S. Oddou-Muratorio, and C. Pichot. 2014. Considering evolutionary processes in adaptive forestry. Annals of Forest Science 71:723-739. https://doi.org/10.1007/s13595-013-0272-1

Legay, M., C. Bastien, J.-C. Bastien, X. Bartet, H. Davi, J.-F. Dhote, A. Ducousso, M. Benito-Garzón, T. Caquet, P. Dreyfus, A. Jambois, F. Lefèvre, B. Marcais, P. Mengin-Lecreulx, C. Micheneau, P. Pinto, C. Plomion, and T. Sardin. 2015. Adaptation: vers un enrichissement du dialogue recherchegestion. Innovations Agronomiques (47):121-130.

Leroux, L. 2016. Du charbon à la biomasse, la conversion contestée de la centrale de Gardanne. Le Monde, 8 March.

Leroux, L. 2017. L'Etat accorde un sursis au plus grand projet de biomasse en France, à Gardanne. Le Monde, 8 June.

Lindner, M., J. B. Fitzgerald, N. E. Zimmermann, C. Reyer, S. Delzon, E. van der Maaten, M.-J. Schelhaas, P. Lasch, J. Eggers, M. van der Maaten-Theunissen, F. Suckow, A. Psomas, B. Poulter, and M. Hanewinkel. 2014. Climate change and European forests: What do we know, what are the uncertainties, and what are the implications for forest management? Journal of Environmental Management 146:69-83. https://doi.org/10.1016/j.jenvman.2014.07.030

Loustau, D., A. Bosc, A. Colin, J. Ogée, H. Davi, C. François, E. Dufrêne, M. Déqué, E. Cloppet, D. Arrouays, C. L. Bas, N. Saby, G. Pignard, N. Hamza, A. Granier, N. Bréda, P. Ciais, N. Viovy, and F. Delage. 2005. Modeling climate change effects on the potential production of French plains forests at the sub-regional level. Tree Physiology 25(7):813-823. https://doi.org/10.1093/ treephys/25.7.813

Magnusson, M., J. E. S. Fransson, and H. Olsson. 2008. Change detection of thinned Norway spruce stands using optical SPOT-4 satellite data. Canadian Journal of Remote Sensing 34(5):431-437. https://doi.org/10.5589/m08-035

Marino, E., J.-L. Dupuy, F. Pimont, M. Guijarro, C. Hernando, and R. Linn. 2012. Fuel bulk density and fuel moisture content effects on fire rate of spread: a comparison between FIRETEC model predictions and experimental results in shrub fuels. Journal of Fire Sciences 30(4):277-299. https://doi.org/10.1177/0734904111434286

Mariotti, A., Y. Pan, N. Zeng, and A. Alessandri. 2015. Longterm climate change in the Mediterranean region in the midst of 
decadal variability. Climate Dynamics 44:1437-1456. https://doi. org/10.1007/s00382-015-2487-3

Ministerial Statistical Service of Agriculture. 2019. Production de sciages en millier de m3. Agreste, la statistique, l'évaluation et la propsective du ministère de l'Agriculture et de l'Alimentation, Paris, France. [online] URL: https://agreste.agriculture.gouv.fr/ agreste-web/disaron/SCINR01/detail/

Moriondo, M., P. Good, R. Durao, M. Bindi, C. Giannakopoulos, and J. CorteReal. 2006. Potential impact of climate change on fire risk in the Mediterranean area. Climate Research 31:85-95. https://doi.org/10.3354/cr031085

Nel, J. L., D. J. Roux, A. Driver, L. Hill, A. C. Maherry, K. Snaddon, C. R. Petersen, L. B. Smith-Adao, H. V. Deventer, and B. Reyers. 2016. Knowledge co-production and boundary work to promote implementation of conservation plans. Conservation Biology 30(1):176-188. https://doi.org/10.1111/cobi.12560

Nicault, A., S. Alleaume, S. Brewer, M. Carrer, P. Nola, and J. Guiot. 2008. Mediterranean drought fluctuation during the last 500 years based on tree-ring data. Climate Dynamics 31 (2-3):227-245. https://doi.org/10.1007/s00382-007-0349-3

Norby, R. J., E. H. DeLucia, B. Gielen, C. Calfapietra, C. P. Giardina, J. S. King, J. Ledford, H. R. McCarthy, D. J. P. Moore, R. Ceulemans, P. D. Angelis, A. C. Finzi, D. F. Karnosky, M. E. Kubiske, M. Lukac, K. S. Pregitzer, G. E. Scarascia-Mugnozza, W. H. Schlesinger, and R. Oren. 2005. Forest response to elevated $\mathrm{CO}_{2}$ is conserved across a broad range of productivity. Proceedings of the National Academy of Sciences of the United States of America 102(50):18052-18056. https://doi.org/10.1073/ pnas.0509478102

Norby, R. J., and D. R. Zak. 2011. Ecological lessons from freeair $\mathrm{CO}_{2}$ enrichment (FACE) experiments. Annual Review of Ecology, Evolution, and Systematics 42:181-203. https://doi. org/10.1146/annurev-ecolsys-102209-144647

Norström, A. V., C. Cvitanovic, M. F. Löf, S. West, C. Wyborn, P. Balvanera, A. T. Bednarek, E. M. Bennett, R. Biggs, A. de Bremond, B. M. Campbell, J. G. Canadell, S. R. Carpenter, C. Folke, E. A. Fulton, O. Gaffney, S. Gelcich, J.-B. Jouffray, M. Leach, M. Le Tissier, B. Martín-López, E. Louder, M.-F. Loutre, A. M. Meadow, H. Nagendra, D. Payne, G. D. Peterson, B. Reyers, R. Scholes, C. I. Speranza, M. Spierenburg, M. Stafford-Smith, M. Tengö, S. van der Hel, I. van Putten, and H. Österblom. 2020. Principles for knowledge co-production in sustainability research. Nature Sustainability 3:182-190. https://doi.org/10.1038/s41893-019-0448-2

Oddou-Muratorio, S., and H. Davi. 2014. Simulating local adaptation to climate of forest trees with a physio-demo-genetics model. Evolutionary Applications 7(4):453-467. https://doi. org/10.1111/eva.12143

Observatoire Régional de la Forêt Méditerranéenne (OFME). 2018. Données \& chiffres-clés de la forêt méditerranéennes Provence-Alpes-Côte d'Azur. OFME, Gardanne, France. [online] URL: http://www.ofme.org/documents/Chiffres-cles/ Chiffres cles 2018 pl web link.pdf

Olsson, P., C. Folke, and T. Hahn. 2004. Social-ecological transformation for ecosystem management: the development of adaptive co-management of a wetland landscape in southern
Sweden. Ecology and Society 9(4):2. https://doi.org/10.5751/ ES-00683-090402

Paillet, Y., L. Bergès, J. Hjältén, P. Odor, C. Avon, M. BernhardtRömermann, R.-J. Bijlsma, L. De Bruyn, M. Fuhr, U. Grandin, R. Kanka, L. Lundin, S. Luque, T. Magura, S. Matesanz, I. Mészáros, M.-T. Sebastià, W. Schmidt, T. Standovár, B. Tóthmérész, A. Uotila, F. Valladares, K. Vellak, and R. Virtanen. 2010. Biodiversity differences between managed and unmanaged forests: meta-analysis of species richness in Europe. Conservation Biology 24(1):101-112. https://doi.org/10.1111/j.1523-1739.2009.01399. $\underline{\mathrm{x}}$

Pan, Y., R. A. Birdsey, J. Fang, R. Houghton, P. E. Kauppi, W. A. Kurz, O. L. Phillips, A. Shvidenko, S. L. Lewis, J. G. Canadell, P. Ciais, R. B. Jackson, S. W. Pacala, A. D. McGuire, S. Piao, A. Rautiainen, S. Sitch, and D. Hayes. 2011. A large and persistent carbon sink in the world's forests. Science 333:988-993. https:// doi.org/10.1126/science.1201609

Paoletti, E. 2006. Impact of ozone on Mediterranean forests: a review. Environmental Pollution 144(2):463-474. https://doi. org/10.1016/j.envpol.2005.12.051

Phoenix, G. K., W. K. Hicks, S. Cinderby, J. C. I. Kuylenstierna, W. D. Stock, F. J. Dentener, K. E. Giller, A. T. Austin, R. D. B. Lefroy, B. S. Gimeno, M. R. Ashmore, and P. Ineson. 2006. Atmospheric nitrogen deposition in world biodiversity hotspots: the need for a greater global perspective in assessing $\mathrm{N}$ deposition impacts. Global Change Biology 12(3):470-476. https://doi. org/10.1111/j.1365-2486.2006.01104.X

Prévosto, B., L. Amandier, T. Quesney, G. de Boisgelin, and C. Ripert. 2012. Regenerating mature Aleppo pine stands in fire-free conditions: site preparation treatments matter. Forest Ecology and Management 282:70-77. https://doi.org/10.1016/j.foreco.2012.06.043

Saxe, H., D. S. Ellsworth, and J. Heath. 1998. Tree and forest functioning in an enriched $\mathrm{CO}_{2}$ atmosphere. New Phytologist 139 (3):395-436. https://doi.org/10.1046/j.1469-8137.1998.00221.x

Schleyer, C., A. Lux, M. Mehring, and C. Görg. 2017. Ecosystem services as a boundary concept: arguments from social ecology. Sustainability 9(7):1107. https://doi.org/10.3390/su9071107

Sergent, A. 2014. Sector-based political analysis of energy transition: green shift in the forest policy regime in France. Energy Policy 73:491-500. https://doi.org/10.1016/j.enpol.2014.06.008

Serra, P., X. Pons, and D. Saurí. 2008. Land-cover and land-use change in a Mediterranean landscape: a spatial analysis of driving forces integrating biophysical and human factors. Applied Geography 28(3):189-209. https://doi.org/10.1016/j.apgeog.2008.02.001

Seuret, F. 2015. A Gardanne, du renouvelable pas écolo. Alternatives Economiques, 1 May.

Upreti, B. R., and D. van der Horst. 2004. National renewable energy policy and local opposition in the UK: the failed development of a biomass electricity plant. Biomass and Bioenergy 26(1):61-69. https://doi.org/10.1016/S0961-9534(03) 00099-0

Verkerk, P. J., C. Levers, T. Kuemmerle, M. Lindner, R. Valbuena, P. H. Verburg, and S. Zudin. 2015. Mapping wood production in European forests. Forest Ecology and Management 357:228-238. 
Verkerk, P. J., R. Mavsar, M. Giergiczny, M. Lindner, D. Edwards, and M. J. Schelhaas. 2014. Assessing impacts of intensified biomass production and biodiversity protection on ecosystem services provided by European forests. Ecosystem Services 9:155-165. https://doi.org/10.1016/j.ecoser.2014.06.004

Wakim, N. 2019. Daniel Kretinsky signe le rachat de deux centrales à charbon en France... dix-huit mois avant leur fermeture. Le Monde, 4 July.

Walker, B., C. S. Holling, S. R. Carpenter, and A. Kinzig. 2004. Resilience, adaptability and transformability in social-ecological systems. Ecology and Society 9(2):5. https://doi.org/10.5751/ ES-00650-090205

Xu, C., N. G. McDowell, R. A. Fisher, L. Wei, S. Sevanto, B. O. Christoffersen, E. Weng, and R. S. Middleton. 2019. Increasing impacts of extreme droughts on vegetation productivity under climate change. Nature Climate Change 9:948-953. https://doi. org/10.1038/s41558-019-0630-6

Zhang, P., G. Shao, G. Zhao, D. C. Le Master, G. R. Parker, J. B. Dunning, and Q. Li. 2000. China's forest policy for the $21 \mathrm{st}$ century. Science 288(5474):2135-2136. https://doi.org/10.1126/ science.288.5474.2135 